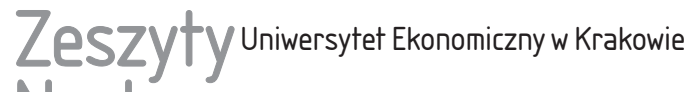 Naukowe
}

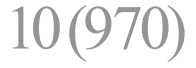

ISSN 1898-6447

Zesz. Nauk. UEK, 2017; $10(970):$ 5-20

DOI: 10.15678/ZNUEK.2017.0970.1001

\section{Foreign Direct Investment in Ghana - the Political Economy Perspective}

\begin{abstract}
Every developmental and economic agenda must seek to attract FDI. Both developed and emerging economies put in place various institutional, legal frameworks and other mechanisms to implement and execute investment agendas. This paper discusses Ghana's situation by examining various programmes the country's government has implemented and institutions that have been established to foster inward investment. Institutions like the Ghana Investment Promotion Centre (GIPC), the Gateway Programme and other reforms within institutions are also presented. The article concludes with a brief overview of the current investment trends in Ghana, the relevance of FDI and the importance of policy direction to protect sensitive sectors of the Ghanaian economy.
\end{abstract}

Keywords: foreign direct investment (FDI), political economy, economic growth, Ghana. JEL Classification: F21, F55, F59.

\section{Introduction and Background}

The main aim of this article is to lay emphasis on the importance of incentives to attract investment. The existence of an efficient political economy towards foreign direct investment is an undisputed fact. In every developmental and economic agenda, the attraction of foreign direct investment (FDI) seems inevitable to ignore, 
as both developed and emerging economies implement various institutional, legal frameworks, and other mechanisms to execute investment agendas for their various economies. This paper discusses the Ghanaian situation by examining various programmes and reforms the government has implemented and institutions that have been established to foster inward investment. The article examines institutions like the Ghana Investment Promotion Centre (GIPC), the Gateway Programme and other institutional reforms. It also discusses the results of some reforms and touches on the importance of joining international bodies like the World Trade Organisation (WTO). The paper ends with a brief overview of the current trend of investment in Ghana and concludes with a look at the relevance of FDI as well as the importance of policy that protects sensitive sectors of the Ghanaian economy.

Countries strive to make their economies competitive and efficient in order to encourage investment from multinational corporations. This approach requires effective institutions and the existence of legal and institutional frameworks to settle disputes among trade partners. The level of transparency and efficiency in host economies is also important as it will help attract foreign and human capital, and also build investor confidence. This will increase not only portfolio investment but also direct investment in the long term. Additionally, a stable and democratic environment will attract voluminous FDI, boosting economic growth. This makes the argument for political economy of foreign direct investment very important and relevant in today's 21st global century. The theme of whether or not political regimes affect the inflow of foreign capital has been the centre of discussion in the political science literature. Authors like G. A. O'Donnell (1978) suggest that authoritarian leaders, in their quest to pursue industrial policies, are more effective than their democratic counterparts at safeguarding multinational corporations' interests. However, no existing evidence shows that authoritarian regimes attract more U.S. foreign investment (Oneal 1994). International investment in the form of foreign direct investment and portfolio investment stimulates the economic growth and development of any economy, a fact upon which a good deal of reserch has focused, much of it particularly on developing and emerging economies. Economic growth and sustainable development are influenced by both endogenous and exogenous factors, of which foreign direct investment forms a huge part.

Aside from the inflow of foreign capital and the growth it induces, there is also a need for efficient and effective instiutional development to complement these efforts. The development of a cautious and efficent financial system is crucial as it acts as a channel for growth. Economic growth can be financed and requires the creation of institutions to implement policies to enhance investment within an economy. Various economic and political reforms are used in both developing and emerging economies, particularly middle income countries like Ghana. 
The Ghanaian economy has experienced massive inflow of foreign capital as a result of some of the factors laid out above.

\section{Theoretical Review}

Numerous empirical studies have examined the impact of FDI and financial sector development on economic growth. More and more have been done since the emergence of endogenous growth theory. The empirical studies have thus far yielded mixed results on whether FDI contributes positively to economic growth (e.g. Balasubramanyam, Salisu \& Sapsford 1996, Borensztein, De Gregorio \& Lee 1998, Carkovic \& Levine 2002, Hansen \& Rand 2006). In the financial development-growth literature, however, the empirical results have been more conclusive. Most studies have found that financial sector development boosts economic growth (e.g. Christopoulos \& Tsionas 2004, King \& Levine 1993, Levine, Loayza \& Beck 2000). More recent studies have shown that the growth impact of FDI will depend on the extent of financial sector development in host countries (Hermes \& Lensink 2003, Alfaro et al. 2004). Despite this, the number of empirical studies examining this complementary impact has been relatively small. Most of the cross-sectional empirical studies have not been region-specific, except for the study by M. Omran and A. Bolbol (2003) which focuses on Arabic countries. Few studies have examined the role of financial sector development in enhancing the contributions of FDI on economic growth in Ghana, which has undergone rapid economic growth over the last decade.

Recent developments in growth theory have considered various sources of long-run growth, each of which involves an externality associated with some activity. Examples include human capital accumulation through either learning by doing or education and technological advance through R\&D activities. Policy makers and academics contend that FDI can have important positive effects on a host country's development effort, but that empirical evidence for it generating positive spillovers for host countries is ambiguous at both the micro and macro levels. In a recent survey of the literature, G. H. Hanson (2001) argues that evidence that FDI generates positive spillovers for host countries is weak. But V. N. Balasubramanyam, M. Salisu and D. Sapsford (1996) found that when developing countries pursue outward-oriented trade policies, FDI inflows are yield faster growth than in those developing countries that pursued inward-oriented trade policies.

In their paper on the effectiveness of FDI on economic growth, N. Erum, S. Hussain and A. Yousaf (2016) concluded that although FDI is important, it is not more so than domestic investment. They argued that the effectiveness of domestic capital is more reliable and consistent with reference to economic 
growth. The loss of government revenue due to fiscal decisions on tax exemptions is noted as a drawback of FDI. Other studies identifying bidirectional causality between FDI and economic growth include S. Naz, G. M. Sabir and A. Mamoon (2015), who concluded that FDI has a positive effect on economic growth while inflation, among other factors, hamper it. I. Ullah, M. Shah and F. U. Khan (2014) found a "bidirectional causal association between domestic investment and FDI whereas domestic investment causes economic growth and economic growth causes FDI". This recent work throws more light on the importance of domestic investment as a good and relevant source of investment. N. Chayawisan (2015), Z. U. Rahman (2014), A. M. M. Mustafa and S. Santhirasegaram (2013), D. Saqib, M. Masnoon and N. Rafique (2013), J. E. Chen and S. A. M. Zulkifli (2012) all find a positive bi-directional relationship between FDI and economic growth. C. Jude and G. Levieuge (2014) stress the importance of effective institutional bodies, for without them, the effects of FDI in developing economies will not be possible.

\section{Economic Outlook - the Benefits of Economic and Institutional Reforms}

Belonging to and appending signatures to international institutions, traderelated treaties attract volumes of FDI in various forms (Büthe \& Milner 2008). WTO rules, International Monetary Fund (IMF) agreements and numerous other trade agreements ensure that individual member countries stay committed to a well-defined set of liberal economic policies, thus preventing deals from becoming obsolete and ensuring individual member countries' commitments are dependable. Research J. Goldstein and L. L. Martin (2000) determined that one benefit of international institutions is that they create disincentives for states to behave opportunistically by reneging on trade agreements and acting unilaterally. International institutions like the WTO and other bilateral trade agreements enshrine provisions and provide remedies for all parties to a trade deal.

Authors including Schiff and Winters (1998) also note that international institutions ensure potential gains from economic growth, increased investment and location advantages. For FDI to be successful, there must be a conscious effort on the part of governments to continue policies and programmes and to reassure investors when regime change occurs. This insurance insures investors against nationalisation and the freezing of assets (Fernandez \& Portes 1998, Simmons 2000, Büthe \& Milner 2008). With regard to integration agreements, M. Blomström and A. Kokko (1997) point out the serious challenges posed by regional integration and the different dynamics of FDI. M. Busse (2003) concluded that democratic regimes tend to attract FDI. N. M. Jensen (2003), in contrast, believes democratic institutions 
tend to inhibit flexibility vis- $a$-vis the implementation of domestic policy. Jensen's voice is not singular: There is a host of other studies suggesting that democracies do not really attract FDI (Yang 2007). Nonetheless, O. Li and A. Resnick (2003) assert that under democratic regimes investors are safe form asset nationalisation and seizures but are entitled to their property rights. Levels of deregulation and home-grown (domestic policies) policies in various economies have encouraged and attracted foreign investors. Openness to trade has become a pivotal point in most economic agendas as globalisation involves voluminous investment. To enable and boost FDI, governments and other investment authorities negotiate international agreements, memorandums of understanding and sometimes - preferential trade agreements to pull in multinational corporations. These agreements normally are signed within the scope of membership in organisations like the WTO and the General Agreements on Tariffs and Trade (GATT), whose guidelines signal a good outlook for investors.

To become part of these international institutions and reap the benefits of international trade, countries must ensure they have the requisite institutions and infrastructure in place both domestically and internationally. In reforming its economy, Ghana introduced and implemented the Structural Adjustment Programme proposed by the IMF in 1983, and two years later joined the WTO. Political and economic reforms - including the banking and financial industry - continue in order to meet internationally accepted standards and attract investors (Antwi-Asare \& Addison 2000). These changes have generated unprecedented rates of economic growth and made Ghana a major investment destination. The country has maintained strong trading ties with trading partners including the United States and the countries of the European Union and the African Union. It has also become a strong influential member of sub-regional trading blocs, namely the Economic Community of West African Countries (ECOWAS) and the New Partnership for Africa's Development (NEPAD) (see more: http://www.nepad.org/about, accessed: 4.08.2017) and also recently on the debate on signing an Economic Partnership Agreement with the EU (http://www.myjoyonline.com/opinion/2014/May-15th/ ecowas-epa-and-wto-compatibility.php, accessed: 4.08.2017).

Since 1983, Ghana's financial sector has been restructuring and undergoing transformation. These have included reforms in the financial sector in 1983 under the Structural Adjustment Programme, the Financial Sector Adjustment Programme (FINSAP) in 1988 in two phases, financial liberalisation in 1990 and the introduction of universal banking in 2003. All of these sought to build and create a vibrant financial architectural framework facilitating the transition to a market economy. Whiles FINSAP made gains in the banking sector, it is also credited with establishing Ghana's capital market. Further boosting investor confidence, the Ghana Stock Exchange that was incorporated in July 1989 as a private entity 
under the Companies Code of 1963 (Act 179), went public in April 1994 to ensure proper governmental and institutional oversight of its trading activities.

Pushing for full liberalisation in the financial sector, "universal banking" was introduced by the Bank of Ghana in the first quarter of 2003. This allowed banks to embark on commercial, development, investment or merchant banking without separate requirements to operate in these new areas. Financial sector development coincided with a period of strong growth. Gross domestic product increased from $-7.5 \%$ in 1982 to $6.2 \%$ in 2006, while per capita income increasing from $-10.2 \%$ to $4.3 \%$ over the same period (World Development Indicators 2008). These reforms have boosted financial sector effectiveness and efficiency, resulting in positive economic growth since the start of the economic adjustment period and consistently since 1990, especially from 2001 to 2013.

Ghana's economic growth rate and expansion is not only a regional concern but has implications on international decision-making processes regarding investments in Africa. Some of the major drivers of the Ghanaian economy include mining, agriculture, the petroleum (oil and gas discovery), and financial services, a sector that has grown as the number of banks has increased. For investments to yield the desired returns, energy production must play a central role in the economy. In Ghana, the completion of the Bui hydroelectric dam in 2013 together with gas production in Atuabo, which started in 2014, has enhanced the supply of electricity for production purposes. This in turn has improved manufacturing and services sector output. The robust nature of the financial sector and continuous improvement in the telecommunications and transport sector remain positive drivers, and a strong basis for attracting investment. Another advantage Ghana possesses is its political stability, good governance, and respect for the rule of law and good business environment.

The economic recession of 2008 caused economic growth to slow, but growth continued after reforms and other government efforts at fiscal consolidation were made. Monetary and fiscal policies implemented in the wake of the 2008 financial meltdown and other implemented policies had a positive impact on infrastructure and also increased investment. Ghana's strong export regime also boosted the economy, with major trading partners in Southeast Asia, the US and the EU importing more. The economy later made strong progress thanks to fiscal consolidation lowering the fiscal deficit of $6.3 \%$ in 2015 . While the economy missed its fiscal target of 5.3\% of gross domestic product in 2016, it achieved grew $3.6 \%$ more than the $3.3 \%$ projected. The inflation rate of $15.4 \%$ in December 2016 fell to $13.3 \%$ in January 2017, closer to the 6-10\% range the Central Bank was calling for (http://www.worldbank.org/en/country/ghana/overview/, accessed: 1.07.2017). These figures demonstrate Ghana's prudent economic management. 
Even with global weakness and imbalances, together with weak global commodity prices, Ghana's external balance improved in 2016, reflecting increased exports and falling imports. The current account deficit narrowed to $6.4 \%$ of GDP in 2016 from 7.6\% of GDP in 2015. Foreign reserves surged from 4.4 billion USD to an estimated 4.9 billion USD, boosting Ghana's balance of payment accounts (http://www.worldbank.org/en/country/ghana/overview/, accessed: 1.07.2017). Furthermore, bolstered by improved oil and gas production, increased private-sector investment, improved public infrastructure development and sustained political stability, growth is still expected to be positive (http:// www.afdb.org/countries/west-africa/ghana/ghana-economic-outlook/, accessed: 5.08.2017). These macroeconomic developments are all expected to encourage investment in the long term.

Ernest and Young (E\&Y) recently cited the Ghanaian economy as new a regional hotspot for global investment and doing business (http://www.ey.com/ GL/en/Newsroom/News-releases/News-foreign-direct-investment-in-subsaharan-africa-on-the-rise, accessed: 4.08.2017). Massive investment holdings have been held by major investors, i.e. The United States, the countries of the EU, the United Kingdom and China. Investment is expected to increase thanks to the favourable conditions and economic stability that continues to flourish in the country. The emergent Ghanaian economy has stepped into the global spotlight alongside other major regional competitors Nigeria, South Africa and Kenya, all of which compete for investments on the African continent. Considerable FDI over the decades has strengthened Ghana's economy and increased its financial markets' base of capital. Other financial and banking sector reforms in addition to equity markets developments keeps investors attracted to the Ghanaian economy.

With the country attaining a lower middle-income status (http://www.imf. org/external/pubs/ft/survey/so/2013/car061213a.htm, accessed: 5.08.2017), managing the economy quite effectively and maintaining a stable political environment, Ghana has had a positive impact on Africa's economic outlook. These achievements translate into advantages for some African economies, while also having significant implications for western policy towards the continent's developmental agenda. In a critical starting point, it is relevant to understand the diverse impact of the inflow of FDI and other forms of economic assistance to the African continent. The majority of African economies are being affected indirectly by the phenomenal growth of Asian economies (particularly China's) and their increased trading quota with the continent.

It is clear that African countries must not give up on their growth momentum and their determination to tackle developmental problems, nor on attaining the renewed vision of a prosperous, vibrant region as captured partly in the Millennium development goals, which include halving extreme poverty rates 
especially (see more: http://www.un.org/millenniumgoals/, accessed: 5.08.2017). From a policy perspective, the establishment of the China-Africa Forum offers unconditional support for the African Union and other various programmes, including the New Partnership for African Development (NEPAD), which is being integrated into the sub-regional and national development strategies to attract more investment. Furthermore, economic and trade agreements with the European Union and United States must be negotiated in good faith to have value for the continent's vast natural resources, which are the main driving force for growth and investment on the continent.

\section{The Political Economy of Foreign Direct Investment in Ghana}

\subsection{FDI and Trade Policies}

Government policies and rules regarding the investment climate in a given economy is of utmost importance to investors. Both advanced and emerging economies regard investment, including FDI, crucial to the development processes. FDI significantly stimulates economic growth in both developed and emerging economies. The capacity of an economy to absorb the vast benefits and spillover of FDI depends on the capital base and the ready availability of skilled labour to apply modern technology in production processes and the delivery of services.

\subsection{Ghana's Legal Framework and Investment Policy}

The Promotion Act (Act 478) of 1994 established the Ghana Investment Promotion Centre (GIPC), with the aim of attracting foreign and domestic business and monitoring their business operations. The GIPC encourages, promotes and facilitates investment in Ghana consistently with the country's economic policy goals and also registers projects. China's investments benefit immensely from Ghana's good infrastructure and financial sector development. The investment climate and better legal and administrative nature of the economy makes doing business straightforward. Between 1982 and 1992, Ghana implemented the Strutural Adjustment Programme (SAP) ${ }^{1}$, which was accompanied by various transformations, including the signing of varoius trade treaties and agreements with the WTO, and also the liberalisation of the financial sector, which encourages foreign investment. Ghana's liberal FDI policy makes the country

\footnotetext{
${ }^{1}$ See more: http://dspace.knust.edu.gh:8080/xmlui/handle/123456789/2969 (accessed: 5.08.2017) - for detailed information on the SAP implemented from 1982-1992, see the Ministry of Finance and Economic Affairs.
} 
a safe destination for investment opportunites, and moves the wealth of its natural resources to the fore.

Investment regulations allow foreign investors to employ foreign nationals in Ghana. The GIPC's investor-targeting strategy has identified China as one of ten countries with the potential to increase investment in Ghana and plans to open an office in Shenzhen, a sub-provincial city in Guangdong province, to facilitate investment between China and Ghana. Investment forums and missions staged in both Ghana and China will now implement development plans to improve language integration, drive investment and promotional activities (see more: Looking East... 2009). One also has to state that Ghana enjoys high levels and volumes of investment from other developmental partners including the UK, the US and the EU.

\subsection{Special Economic Zones and the Gateway Programme}

In 1995, the Parliament of Ghana promulgated the Free Zones Act that was later signed in to law. This Act of parliament was intended to accelerate the exploration of the country's potential. In order to assist the activities of Ghana's export processing zones (EPZs), the Ghana Free Zones board was established to help monitor activities. The EPZs are aimed in particular at the industrial sector, located physically and administratively without and outside the jurisdiction of the customs barrier. Ghana's special economic zone is focused largely on export production. This zone helps attract investors into various sectors by providing incentives through an administrative and policymaking body, when it relates to investment. The main objective of the Investment Act is to attract FDI. To achieve these investment objectives, there are some provisions allowing for: a ten-year tax exemption on income or profit; a minimum tax of $8 \%$ after 10 years of business operation; tax withheld on dividends accruing from free zone investments; and the opportunity to hold $100 \%$ of the shares in any free zone venture. Finally, the Investment Act also assures the repatriation of earned profits and prevents the nationalisation of assets in the event of government or regime change. All these elements and policies are intended to facilitate the conducting of business, boost investor confidence and foster a positive investment climate.

Another crucial policy tool to enhance and attract investment is the NEPAD (Abodakpi 2012, p. 34-35). Intended to position Ghana as an investment and trade destination hub in West Africa, this gateway programme emphasises export processing zones and FDI as it seeks to attract financial services, transport and telecommunication networks that will facilitate the transfer of processed and finished goods for exports. The emphasis is on developing three exportfree zones by private operators, while the government provides the framework for investment to advance the programme. The Programme is also focused on 
ISO 9000 and International Chamber of Commerce (ICC) standards (Abodakpi 2012, p. 34-35).

\section{Investment Motives}

For multinationals, the most important and common incentives to motivate an investment are mainly: seeking efficiency, seeking resources and seeking markets (Dunning 1993, p. 78). Adequate availability of natural resources combined with unskilled, skilled and semi-skilled labour and the presence of a well-developed infrastructure encourages resource-seeking investment, as in the case of China in most of Africa and other parts of the world. The abundance of raw materials provides a comparative advantage and creates the possibility of trade. Resource seeking investment takes place rapidly when there is a lack of an adequate capital base to develop the vast base of resources or when there is a shortage of skilled and professional knowledge to apply (UNCTAD 1998).

The process of investment is encouraged when there exists a huge addressable market in terms of population size and per capita income. New unsaturated markets give firms the chance to compete and grow, thereby making specialisation a goal in gaining economies of scale. In assessing the size of markets, China sees the Sub-Saharan African corridor as one massive investment hub and other regional blocks as investment destinations. Individual countries including Nigeria, Ghana, Kenya, South Africa and other investment hotspots provide markets for China's manufacturing and production capabilities.

Finally, the motivation to efficiently seek FDI is "to rationalise the structure of the established resource base or market-seeking investment in such a way that the investing company can gain from the common governance of geographically dispersed activities. The point in efficiently seeking MNE is to take advantage of different endowments, cultures, institutional arrangements, economic systems and policies and market structures by concentrating production in a limited number of locations to supply multiple markets. To seek foreign production efficiently, crossborder markets must be both well-developed and open, so regionally integrated markets tend to flourish" (Kudina \& Jakubiak 2008). It should also be noted that multinationals do combine all the above motives when seeking investment proposals.

\section{Current Trends of Foreign Direct Investment in Ghana}

The inflow of FDI volumes has been steady in the period following the global recession of 2008, but overall “(...) Ghana has been one of the world's fastestgrowing economies, on the back of the emergence of its oil industry and underpinned 
by its political stability and the strength of its other commodity sectors. While GDP growth is expected to slow this year, the Ghana Investment Promotion Centre (GIPC) is targeting a $20 \%$ increase in foreign direct investment (FDI), following a dip in 2013" (http://www.oxfordbusinessgroup.com/news/ghana-targets-20-fdiincrease-2014, accessed: 6.08.2017). This trend will likely continue to be positive. The World Bank's “Doing Business 2014" ranks Ghana 67th out of 189 countries one of the best performing economies in Africa and above some European Member States. Ghana's business environment has improved to 28th in the world for accessing credit facilities and 34th for investor protection (http://www.oxfordbusinessgroup. com/news/ghana-targets-20-fdi-increase-2014, accessed: 6.08.2017).

Table 1. Top 10 Source of Investment by FDI Value (2017)

\begin{tabular}{|l|c|c|}
\hline \multicolumn{1}{|c|}{ Countries } & FDI Value (Million USD) & FDI Value (\%) \\
\hline France & 127.83 & 64.75 \\
\hline Others (not specified) & 20.00 & 10.13 \\
\hline China & 17.80 & 9.02 \\
\hline USA & 9.06 & 4.59 \\
\hline Mauritius & 5.98 & 3.03 \\
\hline Switzerland & 5.50 & 2.79 \\
\hline India & 3.22 & 1.63 \\
\hline Netherlands & 3.20 & 1.62 \\
\hline Turkey & 2.72 & 1.38 \\
\hline South Africa & 2.10 & 1.06 \\
\hline Total & 197.41 & 100.00 \\
\hline
\end{tabular}

Source: the author's own calculations based on (GIPC 2017a, p. 3).

FDI accounts for 203.74 million USD (98.55\%) of total value, while about 3 million USD (1.45\%) accounts for the local currency component with total foreign equity amounting to 36.32 million USD. During the second quarter of 2017, 19.64 million USD was also realised as an initial equity transfer. Analysing the countries with numerous projects, China still tops the list with 11 projects, while France is first by estimated value of projects, at 127.83 million USD (for further details see GIPC 2017b).

In the second half of 2017, the total number of projects registered was 46, 35 of which were foreign owned, representing $76 \%$ and with an estimated value of 61.75 million USD accounting for almost $30 \%$ of the total value of projects. Of these investments, 11 were joint ventures between Ghanaian and foreign partners with an estimated value of 144.98 USD. The distribution of registered Ghanaian projects also saw significant improvements, with 20 investments across 
Table 2. Top 10 Investor Countries by Value of FDI (2017)

\begin{tabular}{|l|c|c|}
\hline \multicolumn{1}{|c|}{ Countries } & FDI Value (Million USD) & FDI Value (\%) \\
\hline Netherlands & $2,437.60$ & 77.85 \\
\hline India & 405.36 & 12.95 \\
\hline France & 128.83 & 4.11 \\
\hline United Kingdom & 49.71 & 1.59 \\
\hline China & 44.84 & 1.43 \\
\hline Others (not specified) & 20.00 & 0.64 \\
\hline USA & 15.39 & 0.49 \\
\hline Canada & 12.08 & 0.39 \\
\hline Kenya & 9.19 & 0.29 \\
\hline Mauritius & 7.98 & 0.25 \\
\hline Total & $3,130.98$ & 100.00 \\
\hline
\end{tabular}

Source: the author's own calculations based on (GIPC 2017a, p. 6).

ten regions of the country. The capital city of Accra registered the highest number of projects, at 14, with the service sector registering eight of those. The economic benefits of these projects also have created about 497 jobs that will also affect the national GDP. China has managed a place in the top 10-investor countries since establishing trade and economic relations with Ghana (GIPC 2017b).

\section{Conclusion and Summary}

Within the legal and institutional framework for investment in Ghana, the GIPC promotes investment and is mandated to promote and attract foreign direct investment to the country. The contribution of FDI to Ghana's yearly GDP cannot be underestimated, hence there is a need to put institutions and mechanisms in place to facilitate the attraction and retention of all forms of investment, form medium to long-term ones.

The effects and implications of attracting FDI bears a diversity of outcomes. Employment of both skilled and unskilled labour has been a major positive factor in Ghana. Training and technological transfers have been made available, together with spillovers into the various sectors. The employment of skilled experts boosts the human development index in the long run, as efficient methods are introduced and scare resources of production are utilised properly. On the other hand, it is clear that the quantity of commodities exported from Ghana to other trading partners is abysmally lower than the percentage and volume of imports to Ghana from China (see more: Looking East... 2009). The manufacturing sector of the 
Ghanaian economy and other African countries like South Africa and Nigeria are missing out on trade opportunities with China and other Asian economies.

Because of the increased and growing investment from Asia, especially Chinese business and investment with majority shareholder control, the industrial sector is challenged by the import of highly subsidised manufactured goods. This competition poses both internal and international challenges to Ghana's total output and the pricing of its goods and services. The relative smaller size of the Ghanaian economy and the stiff competition it faces due to globalisation, market liberalisation and deregulation policies should not be ignored by policymakers. Governments must put policies and regulations in place to protect infant and growing industries in all sectors of the economy.

Another area of serious concern is Ghana's textile industry. The sector faces unequal competition, due to heavily subsidised and inexpensive Chinese textiles flooding the markets, making it difficult to sell quality products produced in Ghana. Policy directions towards certain sensitive areas of the economy should be encouraged to protect and enhance both the development of local industries and national pride. A closer examination of investment trends in most African and other emerging economies clearly shows why China is interested in trade, and it is for numerous reasons. Economic interest in the continent's vast natural resources, including raw materials for the textile industry, metals and the recent discovery of petroleum fields increases the appetite not only for Chinese investment but also for also western multinationals. Intra- and inter-African trade and investments should be encouraged, as this will boost confidence in the continent's efforts to develop.

One very recent important challenge for the Ghanaian economy has been the proper management of the country's currency against other major currencies. The recent devaluation of the Cedi due to huge trade and current account imbalances poses problems for both domestic and international investors. For instance, in 2013 the currency plummeted 15\% against the USD, making it one of the worst performing currencies at that time. Fortunately, it has since stabilised. Numerous measures and mechanisms have been implemented to protect the currency and boost investor confidence in the economy after a series of weak exchange rate positions in recent years. Despite all these setbacks, the country remains one of the largest FDI recipients in West Africa.

Finally, is a fact that FDI induces economic growth and expansion through various channels, enhances capital formation and transfer technology and increases competition. Economies must also be cautioned against relying too much on FDI-led growth. Governments and institutions must seek alternative sources of growth to diversify their economies and help prevent against external negative shocks. Economies must develop the legal structure that will create and foster a healthy business environment. When local and national business thrives, it is 
easy for multinationals to enter well performing economies, and they are induced to do so. Governments must therefore provide better incentives for local producers to bring out quality products and drive prices down for better competition on the international stage. The development of inward FDI should be the main agenda for most economies, especially in emerging and developing economies. To benefit fully from all of the policies implemented to attract FDI, economies must have the absorptive capacity and human capability to effectively and efficiently accumulate all of the positive spillover effects.

\section{Bibliography}

Abodakpi J. (2012), Multinational Corporations and Spillover Effects in Ghana - A Look at FDI, Its Targets, Impacts, and Potential, unpublished master thesis, Uniwersytet Ekonomiczny w Krakowie, Kraków.

Alfaro L., Chanda A., Sebnem, K. O., Sayek S. (2004), FDI and Economic Growth: The Role of Local Financial Markets, "Journal of International Economics", vol. 64, no 1, https://doi.org/10.1016/s0022-1996(03)00081-3.

Antwi-Asare T. O., Addison E. K. Y. (2000), Financial Sector Reforms and Bank Performance in Ghana, Overseas Development Institute, University of Ghana, London.

Balasubramanyam V. N., Salisu M., Sapsford D. (1996), Foreign Direct Investment and Growth in EP and IS Countries, "The Economic Journal", vol. 106, no 434, https://doi. org/10.2307/2234933.

Blomström M., Kokko A. (1997), Regional Integration and Foreign Direct Investment, NBER Working Paper no 6019, NBER, Cambridge, MA.

Borensztein E., De Gregorio J., Lee J-W. (1998), How Does Foreign Direct Ivestment Affect Economic Growth?, "Journal of International Economics", vol. 45, no 1, https:// doi.org/10.1016/s0022-1996(97)00033-0.

Busse M. (2003), Democracy and FDI, HWWA Discussion Paper no 216, HWWA, Hamburg.

Büthe T., Milner H. V. (2008), The Politics of Foreign Direct Investment into Developing Countries: Increasing FDI through International Trade Agreements, "American Journal of Political Science", vol. 52, no 4, https://doi.org/10.1111/j.1540-5907.2008.00340.x.

Carkovic M., Levine R. (2002), Does Foreign Direct Investment Accelerate Economic Growth?, Institute for International Economics, University of Minnesota.

Chayawisan N. (2015), Interaction between Domestic and Foreign Direct Investment in Thailand, "British Journal of Economics, Management \& Trade", vol 9, no 2, https:// doi.org/10.9734/bjemt/2015/19274.

Chen J. E., Zulkifli S. A. M. (2012), Malaysian Outward FDI and Economic Growth, "Procedia-Social and Behavioural Sciences", vol. 65, https://doi.org/10.1016/ j.sbspro.2012.11.189.

Christopoulos D., Tsionas E. (2004), Financial Development and Economic Growth: Evidence from Panel Unit Root and Cointegration Tests, "Journal of Development Economics", vol. 73, no 1, https://doi.org/10.1016/j.jdeveco.2003.03.002.

Dunning J. H. (1993), Multinational Enterprises and the Global Economy, Addison-Wesley Publishing, Reading, MA. 
Erum N. Hussain S., Yousaf A. (2016), Foreign Direct Investment and Economic Growth in SAARC Countries, "Journal of Asian Finance, Economics and Business", vol. 3, no 4, https://doi.org/10.13106/jafeb.2016.vol3.no4.57.

Fernandez R., Portes J. (1998), Returns to Regionalism: An Analysis of Non-traditional Gains from Regional Trade Agreements, "World Bank Economic Review", vol. 12, no 2, https://doi.org/10.1093/wber/12.2.197.

GIPC (2017a), Annual Investment Report, vol. 13, no 2.

GIPC (2017b), Quarterly Report, vol. 13, no 2.

Goldstein J., Martin L. L. (2000), Legalization, Trade Liberalization, and Domestic Politics: A Cautionary Note, "International Organization", vol. 54, no 3, https://doi.org/ 10.1162/002081800551226.

Hansen H., Rand J. (2006), On the Causal Links between FDI and Growth in Developing Countries, "The World Economy", vol. 29, no 1, https://doi.org/10.1111/j.14679701.2006.00756.x.

Hanson, G. H. (2001), Should Countries Promote Foreign Direct Investment?, G-24 Discussion Paper Series no 9, UNCTAD, Geneva.

Hermes N., Lensink R. (2003), Foreign Direct Investment, Financial Development and Economic Growth, "Journal of Development Studies", vol. 40, no 1, https://doi.org/ $10.1080 / 00220380412331293707$.

Jensen N. M. (2003), Democratic Governance and Multinational Corporations: Political Regimes and Inflows of Foreign Direct Investment, "International Organization", vol. 57, no 3, https://doi.org/10.1017/s0020818303573040.

Jude C., Levieuge G. (2014), Growth Effect of FDI in Developing Economies: The Role of Institutional Quality, DR LEO 2013-11. 2014. <halshs-01014404>.

King R. G., Levine R. (1993), Finance and Growth: Schumpeter Might Be Right, "The Quarterly Journal of Economics", vol. 108, no 3, https://doi.org/10.2307/2118406.

Kudina A., Jakubiak M. (2008), The Motives and Impediments to FDI in the CIS, Global Forum on International Investment, 27-28 March.

Levine R. (1997), Financial Development and Economic Growth: Views and Agenda, "Journal of Economic Literature", vol. 35, no 2.

Levine R. (2003), More on Finance and Growth: More Finance More Growth?, "Federal Reserve Bank of St. Louis Review", vol. 85, no 4, https://doi.org/10.20955/r.85.31-46.

Levine R., Loayza N., Beck T. (2000), Financial Intermediation and Growth: Causality and Causes, "Journal of Monetary Economics", vol. 46, no 1, https://doi.org/10.1016/ s0304-3932(00)00017-9.

Li Q., Resnick A. (2003), Reversal of Fortunes: Democratic Institutions and Foreign Direct Investment Inflows to Developing Countries, "International Organization”, vol. 57, no 1, https://doi.org/10.1017/s0020818303571077.

Looking East: China - Africa Engagement. Ghana Country Case Study (2009), Accra, http://acetforafrica.org/acet/wp-content/uploads/publications/2016/09/Looking-EastGhana-China-Case-Study-2010.pdf (accessed: 6.08.2017).

Mustafa A. M. M., Santhirasegaram S. (2013), The Impact of Foreign Direct Investment on Economic Growth in Sri Lanka, "Journal of Management", vol. 8, no 1, https://doi. org/10.4038/jm.v8i1.7551.

Naz S., Sabir G. M., Mamoon A. (2015), Impact of Foreign Direct Investment on Economic Growth: Empirical Results from Pakistan, "Journal of Poverty, Investment and Development", vol. 12. 
O'Donnell G. A. (1978), Reflections on the Patterns of Change in the Bureaucratic-Authoritarian State, "Latin American Research Review", vol. 13, no 1.

Omran M., Bolbol A. (2003), Foreign Direct Investment, Financial Development, and Economic Growth: Evidence from the Arab Countries, "Review of Middle East Economics and Finance", vol. 1, no 3, https://doi.org/10.2202/1475-3693.1014.

Oneal J. R. (1994), The Affinity of Foreign Investors for Authoritarian Regimes, "Political Research Quarterly", vol. 47, no 3, https://doi.org/10.2307/448844.

Rahman Z. U. (2014), Impact of Foreign Direct Investment on Economic Growth in Pakistan, "Journal of Economics and Sustainable Development", vol. 5, no 27.

Saqib D., Masnoon M., Rafique N. (2013), Impact of Foreign Direct Investment on Economic Growth of Pakistan, "Advances in Management \& Applied Economics", vol. 3, no 1 .

Schiff M., Winters L. A. (1998), Regional Integration as Diplomacy, “The World Bank Economic Review", vol. 12, no 2, https://doi.org/10.1093/wber/12.2.271.

Simmons B. A. (2000), The Legalization of International Monetary Affairs, "International Organization", vol. 54, no 3.

Ullah I., Shah M., Khan F. U. (2014), Domestic Investment, Foreign Direct Investment, and Economic Growth Nexus: A Case of Pakistan, "Economics Research International", vol. 2014, https://doi.org/10.1155/2014/592719.

UNCTAD (1998), World Investment Report 1998: Trends and Determinants, United Nations Conference on Trade and Development, United Nations, New York-Geneva.

World Development Indicators (2008), https://data.worldbank.org/indicator/NY.GDP. MKTP.KD.ZG?locations $=\mathrm{GH}$.

Yang B. (2007), Autocracy, Democracy, and FDI Inflows to the Developing Countries, "International Economic Journal”, vol. 21, no 3, https://doi.org/10.1080/10168730601027179.

\section{Bezpośrednie inwestycje zagraniczne w Ghanie z perspektywy ekonomii politycznej}

(Streszczenie)

Każdy kraj, bez względu na poziom rozwoju (rynki rozwinięte, wschodzące czy rozwijające się), wprowadza w swojej polityce różnorodne ramy prawne i instytucjonalne oraz inne formy rozwiązań, w celu wdrożenia i realizacji własnych planów rozwojowych i inwestycyjnych. Zauważyć można, że stabilna gospodarka i sukcesywne wprowadzanie przyjaznych rozwiązań przyciąga inwestorów oraz przyczynia się do wzrostu bezpośrednich inwestycji zagranicznych. Celem artykułu jest omówienie przypadku Ghany, poprzez analizę różnych programów wprowadzanych przez rząd oraz przegląd instytucji powołanych w celu wspierania wewnętrznych inwestycji. Przedstawione zostały m.in. takie instytucje, jak Ghana Investment Promotion Centre (GIPC), centrum promocji inwestycji w Ghanie, the Gateway Programme (tj. program centrum inwestycyjnego), a także przeprowadzane reformy strukturalne. Omówione zostały również obecne trendy inwestycyjne w Ghanie, znaczenie bezpośrednich inwestycji zagranicznych oraz kierunki polityki gospodarczej mającej na celu ochronę kluczowych sektorów ghańskiej gospodarki.

Słowa kluczowe: bezpośrednie inwestycje zagraniczne (BIZ), ekonomia polityczna, wzrost gospodarczy, Ghana. 